\title{
9 COVID-19, migrant workers, and meatpacking in US agriculture: a critical feminist reflection
}

\author{
Emily Southard
}

The COVID-19 pandemic has revealed many fault lines in our global agriculture system. Despite a long history of critique by scholars and activists, one glaring example is the simultaneous dependence on migrant ${ }^{1}$ workers in agriculture and the way they are treated as disposable. While agriculture-related migration is universal, as a US resident currently living in the agricultural (and my home) state of Iowa, I will focus mainly on the plight of migrant workers here, employed in meatpacking. Migrant workers are the "backbone" of our agriculture system, yet arguably the most vulnerable of all US workers - constrained by the legalization of their humanity, overworked and undervalued, and most notably in the time of COVID-19, treated as expendable.

\section{Broad effects of COVID-19 on migrant workers in US agriculture}

The pandemic has profoundly affected mobility. From March 2020 to March 2021, migration processes and migrant laborers have been severely affected. For many working in the US industrial agriculture system, the reality has been a compulsory "life as normal" as their work is deemed essential and their workplaces deemed critical infrastructure - despite COVID-19 ravaging their workplaces, communities, homes, and bodies. Even before COVID-19, the mobility of these workers was consistently restricted due to legal status, language, poverty, and rurality. Today their mobility is further restricted as international borders have closed, making travel to home communities difficult if not impossible. Moreover, mobility for undocumented migrants is riskier than ever, as unhygienic and densely packed ICE facilities have experienced COVID-19 outbreaks. The Vera Institute of Justice has attempted to track infections at US Immigration and Customs Enforcement (ICE) facilities reported by ICE themselves - as of March 2021, 9,686 cases and 21 deaths 


\section{Emily Southard}

have been reported. However, the Vera Institute's epidemiological model suggests ICE has underreported cases (Smart and Garcia, 2021). Thus, detention for migrants could mean loss of life, long-term health consequences, and trauma, not to mention the forestalling of migrant work's economic benefits.

While effects on mobility are universal, COVID-19's risk to workers in fields and factories depends on the nature of their work, legal status, geographic location, and local response. Workers who do field work may be able to socially distance, yet remain challenged while traveling to work or living in densely packed group quarters, a common migrant housing situation. Workers in industrialized or factory-style workplaces such as milking facilities, mushroom houses, and meatpacking plants face the most risk due to worker density. The infection rates of food sectors depending on their industry of employment has been carefully tracked by Douglas with the Food and Environment Reporting Network since April 2020. Undercounting is an issue even given Douglas's thorough data collection, as it still relies on reports from companies, local governments, and media. However, the data demonstrates how meatpacking workers have been disproportionately affected. As of March, 2021, 88,022 food sector workers have contracted COVID-19 with the vast majority - 57,526 workers - employed in meatpacking. Further, 375 food sector workers have died as a result of the virus, 284 of these deaths those of meatpacking workers (Douglas, 2021). Thus, I will now turn to my home state of Iowa, where meatpacking has exemplified the worst effects of COVID-19, due to the intersection of such work's risk and precarity, critical infrastructure status, and the structured vulnerability of workers.

\section{Case study of meatpacking}

Approximately 40 percent of meatpacking workers $-175,000$ people - are migrants, and "meatpacking has the fifth-highest concentration of refugee workers" (Groves and Tareen, 2020). Migrant refugee workers are highly concentrated in Iowa's meatpacking industry which employs an average of 26,543 people (Stuesse and Dollar, 2020). Iowa has the second largest number of meatpacking workers in the country, following neighboring Nebraska. Pork plants dot the landscape where hogs outnumber people seven to one - JBS in Marshalltown and Ottumwa; Tyson in Waterloo, Columbus Junction, Independence, Storm Lake, Council Bluffs, and Perry; and Seaboard Triumph in Sioux City - just to name some of the major plants. Cattle and poultry are also processed here, at Iowa Premium Beef in Tama or Agri Star in Postville (formerly Agriprocessors, site of the infamous 2008 raid which led to the detainment and deportation of 398 and 297 Latinx workers, respectively). 
The reliance on migrant workers in the meatpacking industry is an intentional product of how the sector is structured to maximize profit and minimize worker resistance. In the 1980s and 1990s, following consolidation of the industry, meatpacking plants sprung up across the rural Midwest. Work in these factories was mechanized and deskilled, meaning workers did not need to possess particular skills or experience, but rather, needed only to be willing to accept low wages for the dangerous and physically demanding work. "Cheap, easily replaceable labor, therefore, is key to the success of the industrial model in meatpacking" (Champlin and Hake, 2006, p. 55). Migrant workers made ideal candidates for this work for numerous reasons. Due to global inequities, their supply is virtually limitless and they accept wages far lower than US workers would for the same work. Further, migrant workers are unlikely to organize due to language and legal barriers. The fact that migrant workers are largely people of color living in a country founded on white supremacy contributes to a paradigm where workers are seen as machinery, not people, and "not as important as a bag of meat" (Ramos et al., 2021, p. 87).

The diversity of ethnicities, races, and languages of meatpacking workers in rural Iowa may seem like an achievement of multiculturalism. Yet, the reality is that workers (and their families) face a great deal of exploitation, isolation, and challenges in these transnational communities. Meatpacking jobs may pay well comparable to other available livelihoods. However, the average US\$12.50 an hour wage means individuals and families supporting themselves - and potentially remitting to families back home - often live in relative poverty. Residential areas for migrants employed in meatpacking are thus typically visibly shoddier and less well-maintained than areas that house white residents. Natural disasters, including a tornado that hit Marshalltown in 2018 and a derecho that devastated Waterloo in August 2020, have particularly impacted migrant neighborhoods. These poorly constructed and maintained houses and apartment complexes, while affordable, were most vulnerable to the destruction wrought by the high winds of both weather events.

Rural Iowa's healthcare, education, and social service sectors are also not well-adapted to meeting the needs of these diverse and largely impoverished communities. For instance, as of 2019, nearly 20 percent of Ottumwa, Iowa's 4,655 students have limited English proficiency. Their ethnicities and languages are very heterogeneous, representing numerous ethnic groups from Mexico, El Salvador, Myanmar, Sudan, Ethiopia, and more. This diversity includes children of meatpacking workers from the Marshall Islands, whose language, Marshallese, is spoken only by approximately 50,000 people worldwide, making interpreters hard to find. NGOs attempt to fill the gaps between state resources and migrant needs, but 


\section{Emily Southard}

their efforts have been further taxed by challenges presented by COVID19. Plants employ interpreters, and information for employees - such as fliers JBS shared on Facebook in March 2021 about vaccination of workers in Marshalltown - are often provided in English, Spanish, Burmese, and French (for those from central and east Africa). Workers' language skills and legal status already pose issues for worker safety in a dangerous workplace environment where injuries are common (Ramos et al., 2021). Thus, given the pandemic, Joe Henry, vice-president of a national Latino activist group stated "immigrant or undocumented workers may be reluctant to complain about unsafe work conditions. And workers for whom English is not their first language may not fully understand the COVID-19 threat" (Eller, 2020a). Even pre-pandemic, these workers and their families faced numerous challenges, including poverty, poor housing, cultural isolation, inadequate access to state services, safety and work hazards, and legal concerns based on immigrant status. The exacerbation of their marginalization and exploitation is thus unsurprising in the context of the pandemic.

The risk imposed by the tight quarters and quick spread of COVID-19 in meatpacking plants has been compounded by the structured precarity of work in the industry which already positioned workers as dependent and replaceable. Workers, unable to endure lost income or potential reprisals for missing shifts, continue to clock in even when exhibiting symptoms of COVID-19. As documented by The New York Times "One worker [at a Tyson plant in Waterloo, Iowa] who died had taken Tylenol before entering the plant to lower her temperature enough to pass the screening, afraid that missing work would mean forgoing a bonus" (Swanson, Yaffe-Bellany, and Corkery, 2020). The plant's accountability in incentivizing workers with COVID-19 symptoms to continue to work is further substantiated by the fact that "[s]everal workers said the Tyson plant penalized people with 'points' for missing work if they or their families had COVID-19 symptoms" (Czyzon, 2021). Plants such as the Waterloo Tyson shut down for mere days to attempt to implement safety protocols, which were rudimentary at best and ineffective at worst. Workers reported that no major changes had been made and that the nature of the dense workplace required them to forego recommended distancing protocols (Czyzon, 2021). Thus, according to Douglas (2021), as of March 2021, 6,600 meatpacking workers in Iowa have fallen ill with COVID-19 across 26 plants, and 22 have died. These numbers are undoubtedly an undercount. The state of Iowa initially reported 444 cases at the Tyson plant in Waterloo, but county officials later updated that figure to 1031 positive cases out of 1,300 total employees (Foley, 2020; Swanson, Yaffe-Bellany, and Corkery, 2020). Moreover, testing and healthcare may be inaccessible due to language barriers or fears of 
detainment based on legal status, suggesting further undercounting on top of underreporting.

Undercounting and underreporting are made more insidious by the fact that managers and supervisors at the Waterloo Tyson plant clearly knew about the danger workers were facing and exacerbated that danger. Evidence has since revealed that higher-ups instructed interpreters to minimize the risk of COVID-19 and discourage the use of masks. Further, managers and supervisors made bets on infection rates of workers. This intentional deception and betting pool was brought to light by families of workers who died from the virus, who have since raised wrongful death lawsuits. While the lawsuits are ongoing as of March 2021, seven managers were fired from the Waterloo plant as a result of their participation in the betting. Seen in the context of how meatpacking has been structured to exploit those most vulnerable - migrant workers - this betting incident exemplifies the dehumanization of meatpacking workers. Due to their migrant status and the structuring of the industry to deskill and devalue work, migrant workers in meatpacking are treated as machinery, not people. This was echoed by Joe Henry, quoted in the Des Moines Register, who stated explicitly "[m]anagers don't see these people as humans ... [t]hey're just part of the machinery ... [w] orkers are viewed as expendable instead of essential" (Eller, 2020b).

Some government oversight was conducted in relation to COVID-19 spread in meatpacking plants, though the state, at best, failed to protect workers, and at worst, knowingly sacrificed workers' lives to maintain the agricultural economy. OSHA inspected only five of the major meatpacking plants in the state as of September 2020, determining only one plant had violated workplace safety regulations. The plant - Iowa Premium Beef Plant in Tama - was charged a mere US\$957 for undercounting COVID-19 infections reported to the public (Associated Press, 2020). This minor fine for risking the lives of workers, their families, and their communities is particularly concerning when considering how the meatpacking industry has profited from the pandemic. For instance, meatpackers' middle-man status for beef served them to make record high profits in April and May 2020. As a result of panic over meat availability, consumer demand caused prices for beef products to surge. Simultaneously, live cattle prices fell precipitously due to concerns over processing facilities continuing to function given COVID-19 outbreaks. As meatpacking was deemed critical infrastructure by the federal government in late April, plants were forced to stay open and companies reaped the benefits while workers suffered. The "price spread," or profit that meatpackers received during this period averaged US\$279 per hundred pounds of beef, an incredible increase compared to the average price spread from 2016 to 2018 - US\$21 per hundred pounds of beef (Fu, 2020). 


\section{Emily Southard}

\section{Gendered implications}

Much of this situation is gendered. Most obvious is the recorded gender differences in mortality from COVID-19, wherein men are particularly at risk of death from the virus. This is notable as USDA data reports that 75 percent of hired farm laborers are men. While USDA data does not provide a gendered breakdown of migrant farm laborers specifically, it does report that 72 percent of these hired farmworkers are foreign-born. Moreover, studies have demonstrated that migration to the US for this kind of work is mendominated, though with growing numbers of women. In meatpacking specifically, 64 percent of workers are men (Stuesse and Dollar, 2020). These men's gender, migrant, and class identities may also intersect in their willingness and ability to access healthcare services. Norms of masculinity may converge with concerns about language, legal status, and cost, deterring migrant men from seeking healthcare even if ill with COVID-19.

The paradigm of lone man migrant worker has emotional and psychological effects for both migrant, alone and at-risk in a foreign community, and for his family back home. Men migrant workers living in the US alone must face the isolation, fear, and inability to travel, without direct familial support, and often in communities which exclude them due to their race, ethnicity, language, and/or legal status. Numerous studies have also demonstrated that women "left behind" by spousal migration face great emotional strain, even without the compounding effect of a pandemic. As "leftbehind" wives have expressed in normal circumstances that their husband's absence causes them feelings of isolation, loneliness, difficulty in managing financial responsibilities, and difficulty in making decisions in emergency situations, it is doubtless that the increased fear of illness, isolation of lockdowns, and financial strains caused by the pandemic worsen these issues.

Unique gendered implications for women migrant agricultural workers can also be assumed, as previous research has demonstrated emotional stress for mothers who migrate and are unable to fulfill caretaking duties in their home countries, an emotional toll that is exacerbated during the pandemic. Mothers working abroad must not only worry about their own safety while continuing to work and facing exposure to the virus, but also must manage concerns about their children and kin's safety and financial stability. An additional consideration for settled families is school closures, and the increased caretaking duties for women especially, a topic covered by others in this anthology. A personal source working with these communities described how the pandemic has caused a shortage of childcare options, forcing many mothers to choose between losing their livelihoods or leaving children at home unattended. Lastly, constrained economic situations and the stress of the pandemic could worsen household tensions 
and gender-based violence, as seen in previous crises and natural disasters. These concerns about the pandemic's effects on women's increased care work burden, heightened household tensions, and higher rates of domestic violence are again exacerbated by migrant workers' identities. Language and legal status pose serious intersectional challenges on what type of help and resources women may be able to access.

\section{Conclusion}

This chapter only begins to cover some of the numerous intersectional and gendered effects that COVID-19 is having on migrants in agriculture. But this geographically constrained snapshot surfaces some of the depth and breadth of exploitation related to migration in agriculture essential to the modern agrifood system. Exploitation and disregard for migrants' lives are certainly not limited to the farms, fields, and meatpacking plants of the United States, but rather has become part and parcel of the race-tothe-bottom of neoliberal capitalism. The transnational interconnectedness of migrant worker precarity and vulnerability is evidenced by the disproportionate effect the pandemic has had on migrant workers in the United States and beyond. The intersection of migrant workers' racialized, illegalized, and gendered identities in the United States and globally has been structured as demonstrated by the meatpacking industry - to permit workers as little power as possible, leaving them in a highly precarious position, materially and mentally, even in the best of circumstances. COVID-19 has just provided an unfortunate opportunity for the barbaric effects of the globalized division of labor in agriculture to be particularly revealed and for the way that gender interacts in these circumstances to be specifically analyzed.

\section{Note}

1 I use "migrant worker" throughout this piece to include temporary migrant workers, immigrants, and refugees, regardless of legal status.

\section{References}

Associated Press (2020) 'After inspecting 5 meatpacking plants with COVID-19 outbreaks, Iowa regulators only fine \$957', The Gazette. Available at: https:// www.thegazette.com/subject/news/business/after-inspecting-5-meatpacking -plants-where-thousands-of-workers-were-sickened-iowa-regulators-issue-one -fine-957-20200924.

Champlin, D. and Hake, E. (2006) 'Immigration as industrial strategy in American meatpacking', Review of Political Economy, 18(1), pp. 49-70. doi: $10.1080 / 09538250500354140$. 


\section{Emily Southard}

Czyzon, S. (2021) 'Criminal records leave Tyson workers feeling stuck at Waterloo plant', The Courier. Available at: https://wcfcourier.com/news/criminal-records -leave-tyson-workers-feeling-stuck-at-waterloo-plant/article_a4f1577e-5f0d $-51 \mathrm{fd}-8 \mathrm{fb} 3-0 \mathrm{db} 521 \mathrm{e} 052 \mathrm{~b} 8 . \mathrm{html}$.

Douglas, L. (2021) Mapping Covid-19 Outbreaks in the Food System, Food and Environment Reporting Network. Available at: https://thefern.org/2020/04/ mapping-covid-19-in-meat-and-food-processing-plants/.

Eller, D. (2020a) 'Iowa JBS workers tell advocates they're packed in too tight to stay safe from coronavirus', The Des Moines Register, 31 March. Available at: https://www.desmoinesregister.com/story/money/agriculture/2020/03/31/ iowa-meatpacking-workers-space-insufficient-protect-jbs-plant-coronavirus /5087544002/.

Eller, D. (2020b) "Tyson fires 7 managers at Waterloo pork plant tied to alleged betting on how many workers COVID-19 would sicken," The Des Moines Register, 16 December. Available at: https://www.desmoinesregister.com/story /money/agriculture/2020/12/16/tyson-foods-fires-seven-waterloo-iowa-plant -managers-betting-covid-19/3927478001/.

Foley, R. J. (2020) 'Outbreak at Iowa pork plant was larger than state reported', The Washington Post, 22 July. Available at: https://www.washingtonpost.com/ business/outbreak-at-iowa-pork-plant-was-larger-than-state-reported/2020/07 /22/5a47c9fe-cc32-11ea-99b0-8426e26d203b_story.html.

Fu, J. (2020) 'Beef packers' profit margins reach historic levels during the height of Covid-19 plant shutdowns', The Counter, 24 July. Available at: https:// thecounter.org/beef-packers-profit-margins-reached-historic-levels-covid-19 -plant-shutdowns/.

Groves, S. and Tareen, S. (2020) 'U.S. meatpacking industry relies on immigrant workers. But a labor shortage looms', Los Angeles Times, 26 May. Available at: https://www.latimes.com/food/story/2020-05-26/meatpacking-industry -immigrant-undocumented-workers.

Ramos, A. K. et al. (2021) "No somos máquinas” (We are not machines): Worker perspectives of safety culture in meatpacking plants in the Midwest', American Journal of Industrial Medicine, 64(2), pp. 84-96. doi: 10.1002/ajim.23206.

Smart, N. and Garcia, A. (2021) Tracking COVID-19 in Immigration Detention, Vera Institute of Justice. Available at: https://www.vera.org/tracking-covid-19-in -immigration-detention.

Stuesse, A. and Dollar, N. T. (2020) Who are America's Meat and Poultry Workers?, Economic Policy Institute. Available at: https:/www.epi.org/blog/meat-and -poultry-worker-demographics/.

Swanson, A., Yaffe-Bellany, D. and Corkery, M. (2020) 'Pork Chops vs. People: Battling Coronavirus in an Iowa Meat Plant', The New York Times, 10 May. Available at: https://www.nytimes.com/2020/05/10/business/economy /coronavirus-tyson-plant-iowa.html. 